\title{
MOLECULAR DIAGNOSTIC RATIOS TO ASSESS THE APPORTIONMENT OF PETROLEUM HYDROCARBONS CONTAMINATION IN MARINE SEDIMENT
}

\section{RASIO MOLEKUL DIAGNOSTIK UNTUK PENDUGAAN SUMBER KONTAMINASI HIDROKARBON MINYAK BUMI DI SEDIMENT LAUT}

\author{
Agung Dhamar Syakti ${ }^{1,2, *}$ \\ ${ }^{1}$ Center for Maritime Biosciences Studies - Institute for Sciences and Community Service, \\ Jenderal Soedirman University, Purwokerto, Indonesia \\ ${ }^{2}$ Fisheries and Marine Sciences Department-Jenderal Soedirman University, Purwokerto, Indonesia \\ *e-mail: agungsyakti@chemist.com
}

Received 28 August 2016; Accepted 12 October 2016; Available online 29 November 2016

\begin{abstract}
As maritime fulcrum nation, in Indonesia, marine environmental analytical chemistry field is still underdeveloped. So that why this review paper aims to provide a basic understanding of the use some molecular diagnostic indices using n-alkanes indexes and polycyclic aromatic hydrocarbons (PAHs) diagnostic ratios to estimate the source of apportionment of the hydrocarbons contamination and origin. The $n$-alkane chromatograms were then used to characterize the predominance of petrogenic or biogenic either terrestrial or aquatic. Furthermore, characterization allowed discriminating riverine versus marine input. The occurrence of unresolved complex mixture can be an evidence of biodegraded petroleum residues. For aromatic compounds, the prevalence of petrogenic, pyrolytic, and combustion-derived can be easily plotted by using isomers ratio calculation. This paper thus provides useful information on the hydrocarbon contamination origin, especially in marine sediments. Further researches should be undertaken in order to validate the use of molecular diagnostic ratio with isotopic approach.
\end{abstract}

Keywords : marine pollution, environmental chemistry, biomarker, n-alkanes, polycyclic aromatic hydrocarbons

\begin{abstract}
ABSTRAK
Sebagai negara yang beporos maritim, di Indonesia, bidang kajian kimia analitik lingkungan laut masih belum berkembang. Terkait hal tersebut, telaah literatur ini bertujuan untuk memberikan pemahaman dasar tentang penggunaan beberapa indeks diagnostik molekuler seperti penggunaan indeks/rasio diagnostik n-alkana dan hidrokarbon aromatik polisiklik (PAHs) untuk memperkirakan asal sumber dari kontaminasi hidrokarbon minyak bumi. Kromatogram $n$-alkana digunakan untuk mengkarakterisasi dominasi sumber petrogenik atau biogenik baik dari lingkungan daratan atau perairan. Lebih lanjut, hasil karakterisasi dapat membantu pemilahan asal sumber kontaminan baik sungai maupun laut. Kemunculan unresolved complex mixture menunjukan bukti biodegradasi dari residu minyak bumi. Untuk senyawa-senyawa aromatik, indikasi prevalensi sumber petrogenic, pyrolitic, ataupun pembakaran biomasa dapat dengan mudah diproyeksikan dengan menggunakan perhitungan rasio dari isomer-isomer senyawa aromatik. Tulisan ini memberikan informasi yang berguna tentang asal sumber kontaminasi hidrokarbon, terutama di sedimen laut. Penelitian lebih lanjut harus dilakukan untuk memvalidasi penggunaan rasio diagnostik molekuler dengan pendekatan isotop.
\end{abstract}

Kata Kunci : pencemaran laut, kimia lingkungan, biomarker, n-alkana, hidrokarbon aromatik polisiklik

\section{INTRODUCTION}

As a "maritime nation continent," which consists of 13.466 islands and a second longest coastal in the world ca. $99.093 \mathrm{~km}$, Indonesia is often vulnerable from the maritime transport of crude oil 
and oil products by an accidental spill and chronic apportionment both naturally or anthropogenic that contribute to petroleum hydrocarbons contamination in the marine environment. Furthermore, maritime activities such as transportation of oils, domestic transport activity by fishermen and public can result in environmental waste even from downstream to estuairies sites in coastal regions can accumulate many pollutants (organic or inorganic). Biological and ecological effects of petroleum hydrocarbons on marine organisms have been reported by several authors (Liu, Liu, Gardner, Shank, \& Ostrom, 2016; Zheng, Wang, Lei, \& Nan, 2016). Such effects are depend on point and non-point sources of apportionment, bioavailability when pollutant reaches the environment matrices, their environment fate, the ability of the organisms to accumulate and metabolize various hydrocarbons that may lead to alteration of survival and reproduction rate in the environment. The long-term effects of petroleum hydrocarbons in the may result in noticeable ecological changes such as possible impairment of fisheries resources (Yan, Liu, Shi, You, \& Cao, 2016) and changes in microbial community structure (Nayar, Goh, \& Chou, 2004; Syakti et al., 2006).

Although the assessments of hydrocarbons apportionment may be conducted in the water (Drozdova, Ritter, Lendl, \& Rosenberg, 2013), biota (Short \& Springman, 2016) and sediment (Kanzari et al., 2014), the later may provide crucial evidence for overall physicochemical and biological process because of the properties of sediment as end reservoir of hydrophobic pollutant in marine environment. Moreover, there are some techniques available to the analytical chemist to assist in determining the source of the hydrocarbon pollution: age dating, the use of additives and dyes plus oxygenates and weathering patterns and hydrocarbon fingerprinting using gas chromatography and mass spectrometry
(GC-MS) analysis. As we aware that identification of the origin of a contaminant, timing of release and its distribution in the environmental matrices are common issues in environment litigation (Morrison, 2000), this paper address to provide insight the use of the indices based on GC-MS analysis of petroleum hydrocarbons chromatogram profile in order to estimate the source of apportionment of the petroleum hydrocarbons contamination in marine environment emphasizing for the sediment.

\section{Hydrocarbons}

In a marine environment, hydrocarbon compounds have various origins including anthropogenic and natural. Anthropogenic input can be divided into two categories: (i). pyrolytic, when the hydrocarbons are released during the combustion of fossil in daily activities such as transport and industrial process e.g. oil refineries and petrochemical. (ii). Petrogenic, their primary source was entering marine environment during exploration, exploitation, supply and distribution of crude oil and oil products. Another source can be associated with industrial activities, combustion of fossil compounds, oil plants, and refineries, oil waste, urban waste, etc. (Syakti et al., 2013; Kanzari et al., 2014). For instance, the crude oils are constituted by 10 to $40 \%$ of aliphatic and isoprenoid fraction, 30-40 \% of cycloalkane, 10- $30 \%$ of aromatic and a complex mixture of asphaltenes, porphyrins, the nitrogen, sulfur, oxygen containing compounds and heavy metals. (Asia, Mazouz, Guiliano, Doumenq, \& Mille, 2009; Syakti, Asia, Kanzari, \& Umasangadji, 2012) (Figure 1). On the other hand, the natural origin refers to the compounds synthesized or produced by living organisms compounds, geochemical sources both formed during diagenesis and catagenesis in the sedimentary rock, and pyrolytic issued from forest fires and volcanic eruptions. 


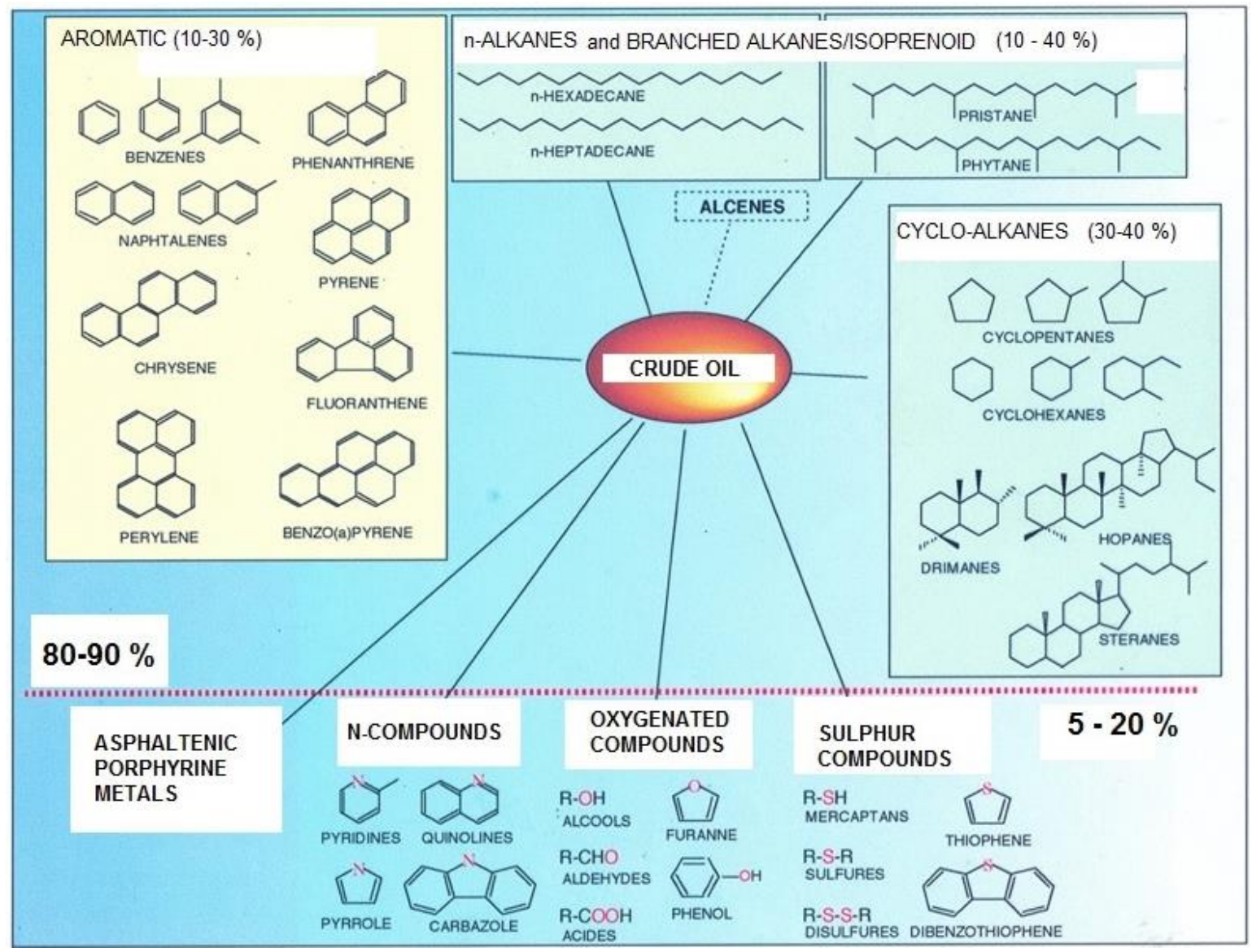

Figure 1. Hydrocarbons classes from a crude oil

\section{Saturated and Isoprenoid Hydrocar- bons}

In this review paper, we limited discussion for apportionment investigation by using aliphatic hydrocarbons such as straight (saturated) and branched (isoprenoid) or which were formed by biological (decarboxylation affecting linear and branched fatty acids), chemical or synthesized process. We exclude nonaromatic (cyclo alkanes) compounds drimane, steranes, and hopanes that are more appropriate for environmental forensic litigation. For the routine monitoring, the saturated hydrocarbons generally have to range from $n-\mathrm{C}_{10}$ to $n$ $\mathrm{C}_{40}$ and might have particular predominance number of atoms $n-\mathrm{C}_{15}$ and $n-\mathrm{C}_{17}$ in the case of marine while the $n-\mathrm{C}_{27}$ and $n-\mathrm{C}_{31}$ in case of terrestrial apportionment (Syakti, Hidayati, Hilmi, Piram, \& Doumenq, 2013). Acyclic isoprenoid hydrocarbons have been found up to $\mathrm{C} 25$. However pristane $(\mathrm{C} 19 ; \mathrm{Pr})$ and phytane $(\mathrm{C} 20 ; \mathrm{Ph})$ are usually the most regarding concentration. Both are considered to be products of the diagenesis of the phytyl side chain of chlorophyll, although other sources are possible. In marine environment, concerning pristane and phytane, (Rontani \& Bonin, 2011) highlighted that procaryote play a role in formation Pr and $\mathrm{Ph}$ in the marine environment during invertebrate feeding, hydrogenation of isomeric pristenes and phytenes from degradation of the chlorophyll phytyl side-chain and/or $\alpha$-tocopherol (vitamin E) to pristane and phytane, respectively, and convert trimeric oxidation products of $\alpha$-tocopherol (produced abiotically in the water column and in the oxic zone of sediments) to pristane. Moreover, thermal maturation of isoprenoid components of archaea (isopranyl glyceryl ethers) also constitutes another potential source of pristane and phytane in thermally mature sediments. 


\section{Polycyclic Aromatic Hydrocarbons (PAHs)}

Polycyclic aromatic hydrocarbons (PAHs) refers to a group of several hundred chemically-related environmentally persistent organic compounds of various structures and varied toxicity. In general, PAHs are considered non-polar molecules, hydrophobic and poorly soluble in water. PAHs may be present in the aquatic environment between two and ten aromatic rings. Also, the low vapor pressure PAHs were very low volatility which decreases with the molecular weight, with the exception of di-aromatic $\mathrm{PAH}$, naphthalene, which can volatilize from the surface of the water or soil (INERIS et al., 2015). Given the marine environmental monitoring, US-EPA recommended 16 PAHs to be monitored (Figure 2).

\section{Hydrocarbons apportionment using saturated and isoprenoid Indices}

Taking into account that aliphatic hydrocarbons can enter the marine environment by natural (i.e. pyrolysis, diagenesis and biosynthesis) and anthropogenic processes (i.e. industrial activities, combustion of fossil compounds, oil plants and refineries, oil waste, urban waste, etc.) (Mille, Asia, Guiliano, Malleret, \& Doumenq, 2007; Syakti et al., 2013; Kanzari et al., 2014), therefore, source of aliphatic hydrocarbons are multiple and difficult to determine. To simplify, molecular indices of aliphatic hydrocarbons i.e. n-alkanes and isoprenoid in sediments can provide information about their sources (e.g., terrestrial vegetation, marine algae or petroleum). There are several ratios for identified sources of apportionment in the marine environment as shown in Table 1 and Figure 3.
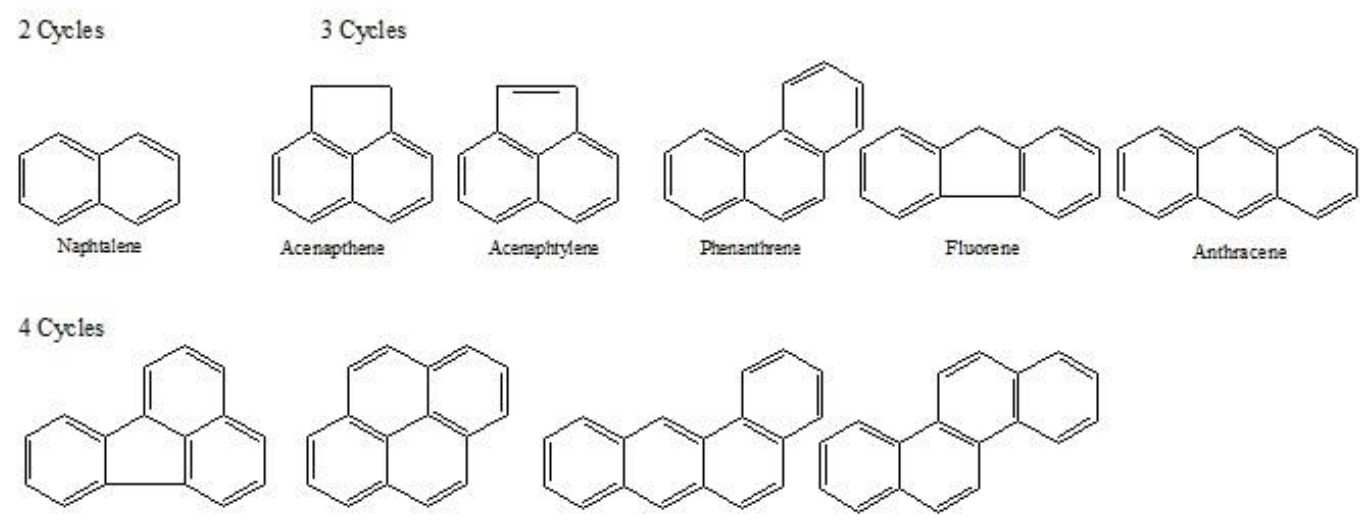

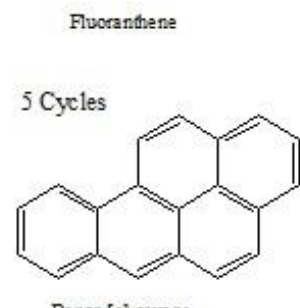

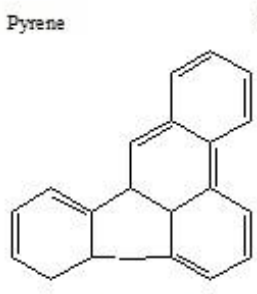

Benzo [a] anthracene

Chrysene

Benzo [b] Fhoranthene

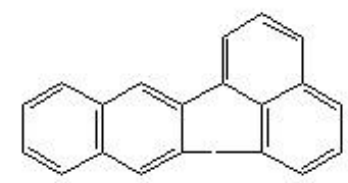

Benzo $[k]$ fluorathene

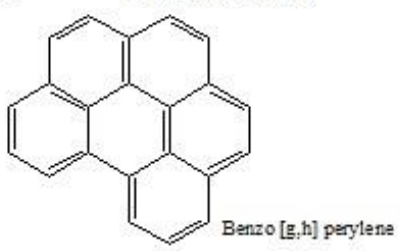

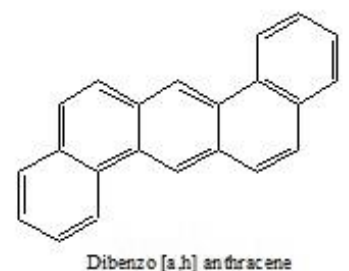

Dibenzo $[\mathrm{a}, \mathrm{h}]$ an furacene

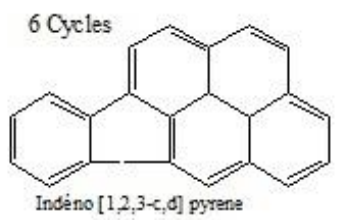

Figure 2. Structure of 16PAHs (US-EPA) 
Table 1. Criteria for distinguishing between petroleum hydrocarbons and biogenic (marine/terrigenous) in the marine environment

\begin{tabular}{cccc}
\hline \multirow{2}{*}{ Indexes } & \multicolumn{3}{c}{ Sources } \\
\cline { 2 - 4 } & Petrogenic & $\begin{array}{c}\text { Marins } \\
\text { biogenic }\end{array}$ & $\begin{array}{c}\text { Terrigenous } \\
\text { biogenic }\end{array}$ \\
\hline $\mathrm{UCM}$ & $++\left(n-\mathrm{C}_{23}-\mathrm{n}-\mathrm{C}_{33}\right)$ & $+\left(n-\mathrm{C}_{15}-\mathrm{n}-\mathrm{C}_{20}\right)$ & - \\
$\mathrm{CPI}(12-36)$ & $\approx 1$ & & $>1$ \\
$\mathrm{NAR}$ & $\approx 0$ & $<<($ weak $)$ & $>>>($ strong $)$ \\
$\mathrm{TAR}$ & & & $>1$ \\
& & $<0.5$ & 1 (mix between \\
$\mathrm{TMD}$ & & & terrigenous \\
& & $<1$ & biogenicand \\
marins $)$ \\
$\mathrm{n}-\mathrm{C}_{29} / \mathrm{n}-\mathrm{C}_{17}$ & $<1$ & $\approx 1$ & $>1$ \\
$\mathrm{n}-\mathrm{C}_{17} / \mathrm{Pr}$ & $>1$ & $\approx 1$ & $\approx 1$ \\
$\mathrm{n}-\mathrm{C}_{18} / \mathrm{Ph}$ & $>1$ & $>2$ & $\approx 1$ \\
$\mathrm{Pr} / \mathrm{Ph}$ & $<2$ & $>2$ \\
\hline
\end{tabular}

Note. $\mathrm{CPI}=$ Carbon Preference Index; NAR $=$ Natural $\mathrm{n}$-alkane ratio; $\mathrm{TAR}=$ Terrigenous/Aquatic Ratios; $\mathrm{Pr} / \mathrm{Ph}=$ Pristane/Phytane ; TMD $=$ Terrestrial Marine Discriminant.

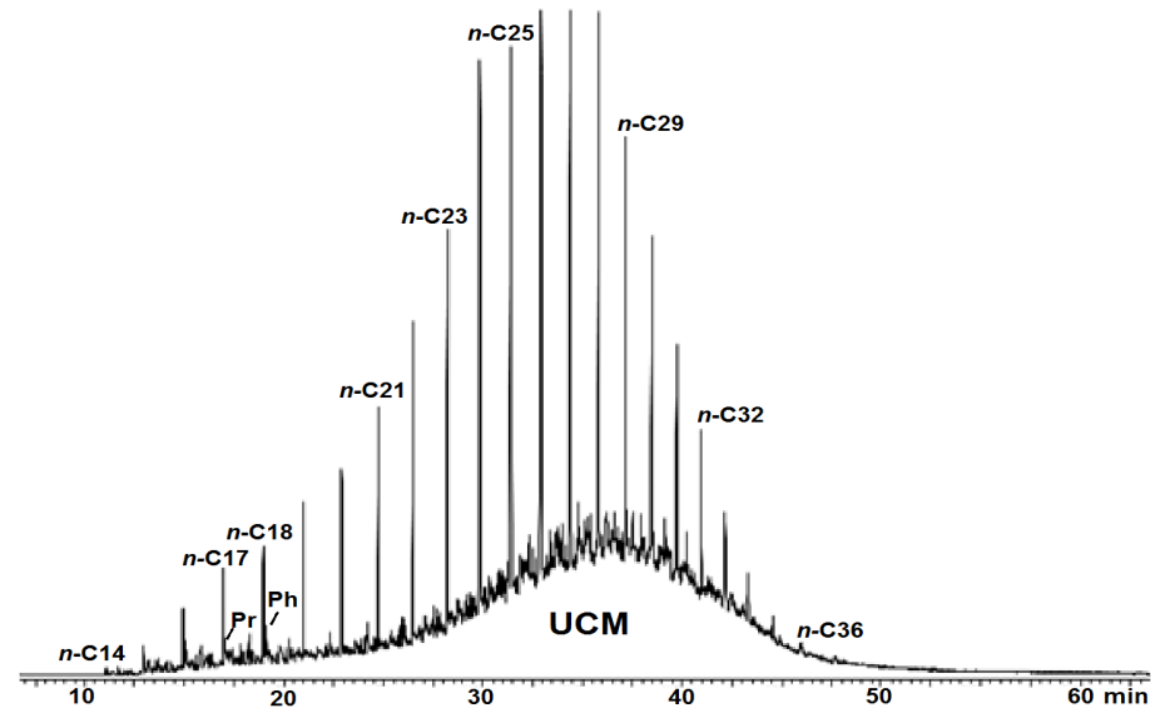

Figure 3. n-alkane chromatogram profile

Unresolves Complex Mixture (UCM)

The UCM has been used extensively for decades to describe a gas chromatographic characteristic indicative of the presence of fossil fuel hydrocarbons (mainly petroleum hydrocarbons) in hydrocarbons isolated from aquatic samples (Farrington \& Quinn, 2015) and has been considered to be the result of many coelutions of structurally of $n$ - alkanes (Mille et al., 2007; Asia et al., 2009). Thus, the presence of UCM indicated the petroleum contamination in marine sediment.

\section{n-Alkane based indices}

Carbon preference indices (CPI)

Firstly introduced by Bray and Evans (1961) and then revised by (Marzi, Torkelson, \& Olson, 1993), CPI derived 
from gas chromatographic analyses have been used for decades. The CPI indicates the ratio between odd numbered $n$-alkanes vs. even numbered $n$-alkanes is around 1 for all crude oils and petroleum hydrocarbons, (Mille et al., 2007 ; Syakti et al., 2013). The value higher than 1 reflected biogenic sources.

$$
C P I_{12-36}=\frac{\left(n C_{13}+n C_{15}+n C_{17} \ldots 7+n C_{35}\right)}{\left(n C_{12}+n C_{14}+n C_{16} \ldots 6+n C_{36}\right)}
$$

In some lesser extent, CPI can be divided into low molecular CPI $\left(<n-\mathrm{C}_{20}\right)$ and high molecular CPI value $\left(>\mathrm{n}-\mathrm{C}_{21}\right)$.

\section{Terrigenous/Aquatic Ratio (TAR)}

The terrigenous/aquatic ratio (TAR) is an indice proposed by (Meyers, 1997) showing the ratio between the concentrations of long-chain n-alkanes $\left(\mathrm{nC}_{27}+\mathrm{nC}_{29}+\mathrm{nC}_{31}\right)$ to short chain $\mathrm{n}$ alkanes $\left(\mathrm{nC}_{15}+\mathrm{nC}_{17}+\mathrm{nC}_{19}\right)$. The principle for this proxy is that $\mathrm{C}_{27}, \mathrm{C}_{29}$, and $\mathrm{C}_{31} \mathrm{n}$ alkanes are characteristic of land plant waxes, whereas $\mathrm{C}_{15}, \mathrm{C}_{17}$, and $\mathrm{C}_{19} \mathrm{n}$ alkanes represent algal input (Meyers, 2003). Several authors have used this indice to discriminate the terrigenous vs. aquatic inputs (Asia et al., 2009; Syakti et al., 2013).

$$
T A R=\frac{\left(n C_{27}+n C_{29}-n C_{31}\right)}{\left(n C_{15}+n C_{17}+n C_{19}\right)}
$$

Natural -Alkanes Ratio (NAR)

NAR has ben used to estimate the proportions of natural and petroleum $n$ alkanes. This ratio close to zero for petroleum hydrocarbons and close to one for higher terrestrial plants or marine plants (Mille et al., 2007).

$$
N A R=\frac{\sum\left(n C_{19}-n C_{32}\right)-2 \sum\left(n C_{20}-n C_{32}\right)}{\sum\left(n C_{19}-n C_{32}\right)}
$$

Terrestrial Marine Discriminant (TMD)

TMD index was proposed by Syakti et al. (2013) in light of TAR and NAR which more particularly discriminate the apportionment from terrestrial versus marine. The term $\mathrm{T}$ is characteristic of higher terrestrial plants (Sikes, Uhle, Nodder, \& Howard, 2009), and M covers marine $\left(n-\mathrm{C}_{17}+n-\mathrm{C}_{19}+n-\mathrm{C}_{21}\right)$ and algal inputs $\left(n-\mathrm{C}_{15}+n-\mathrm{C}_{17}+n-\mathrm{C}_{19}\right)$, as proposed by (Ficken, Wooller, Swain, StreetPerrott, \& Eglinton, 2002). The addition of $n-\mathrm{C}_{23}$ correspond to specific marker for mangrove species (Koch et al., 2011); (Resmi, Manju, Gireeshkumar, Ratheesh Kumar, \& Chandramohanakumar, 2016); and the $n$-alkane signatures of vascular plants and phytoplankton, as proposed in the TAR index (Meyers, 2003). Syakti et al. (2013) reported that a value of 1 occurs when the inputs from terrestrial and marine sources are equal. A value $>1$ is consistent with a dominant terrestrial input, whereas a value $<0.5$ corresponds to a dominant marine contribution. Values between 0.5 and 1 indicate a mixed system, such as an estuary.

$\mathrm{TMD}=\frac{\mathrm{T}}{\mathrm{M}}=\frac{\left(n-\mathrm{C}_{25}+n-\mathrm{C}_{27}+n-\mathrm{C}_{29}+n-\mathrm{C}_{31}+n-\mathrm{C}_{33}\right)}{\left(n-\mathrm{C}_{15}+n-\mathrm{C}_{17}+n-\mathrm{C}_{19}+n-\mathrm{C}_{21}+n-\mathrm{C}_{23}\right)}$

\section{n-Alkanes/Isoprenoid Ratio}

Pristane $(\mathrm{Pr})$ and phytane $(\mathrm{Ph})$ are present in crude oils as a results from post depositional reactions that provide the catalytic hydrogenation of phytadienes and or oxidation $(\mathrm{Pr})$ or the reduction $(\mathrm{Ph})$ of the phytol side chain of chlorophyll. Those branched alkanes are naturally present in zooplankton, algae or bacteria (UNEP/IOC/IAEA 1992; Mille et al., 2007). $\mathrm{Pr} / \mathrm{Ph}$ ratio indicate the degree of maturity of a formation of crude oil source was in oxic condition ( $>1$; mature) or anoxic ( $<1$; immature). Higher ratio value $(>2.5)$ indicates that the oils were derived from mixed terrigenous/marine organic matter (Omotoye, Adekola, Adepoju, \& Akinlua, 2016). Since isoprenoid is less biodegraded compared to their straight chains homolog (n-alkanes), $n$ - $\mathrm{C}_{17} / \mathrm{Pr}$ and $n-\mathrm{C}_{18} / \mathrm{Ph}$ ratios can be used to evaluate the presence of oil and the relative biodegradation of $n$-alkanes. Low values of those ratios indicates the selective biodegradation of petroleum hydrocabons compounds (McIntyre et al., 2007; Syakti et al., 2006). 


\section{Molecular diagnostic using Polycyclic Aromatic Hydrocarbons (PAHs)}

After identification and quantification using appropriate analytical instruments (e.g. GC-MS, HPLC), PAHs diagnostic ratios allow distinguishing between PAH pollution originating from petrogenic, pyrolytic and burning biomass or coal sources. PAH diagnostic ratios can be applied to sediment or other environmental samples. The ratios were based on the comparison between abundance relative of two compounds which have same molecular weight but the different structure (isomers). For instance, Phenanthrene/Anthracene, Fluoranthene/ Pyrene, Benzo(a)anthracene/Chrysene and Indeno (123 cdi) perylene/ Benzo(ghi)pyrene (Yunker \& Macdonald, 2003; Harris, Yunker, Dangerfield, \& Ross, 2011). These compounds have adjacent time retentions. Some application of these molecular diagnostic ratio represented in Table 2.

Anthracene/(Anthracene+Phenanthr ene) can be used to have an indication source of petrogenic (liquid fuels spills) when the value was lower than 0,10 and more than 0,10 was characteristics of pyrolytic (Combustion of fuel) (Budzinski, Jones, Bellocq, Piérard, \& Garrigues, 1997; Commendatore, Nievas, Amin, \& Esteves, 2012). This ration can calculated differently i.e. Phenanthrene/Anthracene ratio, if the values are more than 10 . If the values lower than 10 means the source of PAHs from pyrolytic source (Wang et al., 2009 ; Wang, Xu, Zhou, Wu, \& KanchanopasBarnette, 2015).

Fluoranthene/Fluoranthene+Pyrene value can be useful to evaluate the difference origin of comtamination. When the ratio is less than 0.4 , it can be considered to be characteristic for petrogenic origin (oil, fuel oil, coal). The values between 0.4 and 0.5 indicated a combustion of liquid fossil fuels while the ratio higher than 0.5 was generally be in favor of burning kerosene, grass, coal and wood (Yunker \& Macdonald, 2003; Perra et al., 2011; Commendatore et al., 2012).

Accordingly, the ratio is robust to changes during phase transfer and degradation in the environment. Therefore Fluoranthene/Fluoranthene+Pyrene ratio seems to be more reliable to assess the pollution emission sources. In the other hand, when the ratio was calculated as fluoranthene / pyrene ratio, values below 1 indicate a petrogenic origin while superior values 1 will be for a pyrolytic origin (Culotta, Gianguzza, \& Orecchio, 2005; Commendatore et al., 2012).

The third ratio to validate the differentiate petroleum and pyrolytic origin was Benzo(a)Anthracene/(Benzo(a) Anthracene + Chrysene). The ratio value below 0.2 was representative of a petroleum origin while ratio higher than 0.35 correspond to a pyrolytic origin. The value in between (0.2-0.35) might be stipulated as a mixed origin(Sprovieri et al., 2007; Barakat, Qian, Kim, \& Kennicutt Ii, 2002).

The ratio corresponded to liquid fossil fuel combustion when the value ranged between 0.2 and 0.5 , while a value greater than 0.5 would indicate a combustion of coal or biomass (grass, wood) (Harris et al., 2011; Rajput, Sarin, Sharma, \& Singh, 2014).

On the other hand, other ratios were defined from PAHs parents' isomers $(\mathrm{C} 0)$ and substituted with C1, C2 (alkylated of PAHs) and also from the total of lightweight and heavy weight PAHs (show in Table 2.).

The last simple ratio used was the abundance ratio of low molecular weight ( $\leq 3$ fused rings) and high molecular weight ( $\geq$ four fused rings) (LMW / HMW). The LMW/HMW allowed to distinguishing between petroleum origin (ratio greater than 1) and pyrolytic (reported below 1) (Barakat et al., 2002; Commendatore et al., 2012). 
Table 2. Index characteristics of PAHs sources in marine environment

\begin{tabular}{|c|c|c|c|}
\hline Index & Petrogenic & Mix origins & Pyrolitic \\
\hline Anth/ $/ \sum 178$ & $<0,1$ & & $>0,1$ \\
\hline Phe/Anth & $>10$ & & $<10$ \\
\hline $\mathrm{Fl} / \sum 202$ & $<0,4$ & $\begin{array}{c}0,4-0,5 \\
\text { (combustion of } \\
\text { liquid fossil fuels) }\end{array}$ & $>0,5$ \\
\hline $\mathrm{Fl} / \mathrm{Py}$ & $<1$ & & $>1$ \\
\hline $\mathrm{BzA} / \sum 228$ & $<0,2$ & $0,2-0,35$ (mix) & $>0,35$ \\
\hline $\mathrm{IndP} / \sum 276$ & $<0,2$ & $\begin{array}{l}0,2-0,5 \\
\text { (combustion of } \\
\text { liquid fossil fuels) }\end{array}$ & $\begin{array}{c}>0,5 \\
\text { (cobustion of coal } \\
\text { or biomass } \\
\text { (wood, grass) }\end{array}$ \\
\hline LMW/HMW & $>1$ & & $<1$ \\
\hline $\begin{array}{l}\text { Co (Phe et/ou Anth)/Co+C1 } \\
\text { (Phe et ou Anth) ou Co (Fl } \\
\text { et/ou Py)/Co+C1 (Fl et ou } \\
\text { Py) }\end{array}$ & $>2$ & & $0,5-1$ \\
\hline
\end{tabular}

An: Anthracene; Phe: Phenanthrene; Fl fluoranthene; Py = pyrene; BzA : benzo(a) anthracène ; IndP: indéno $(1,2,3$, cd) pyrène ; LMW/HMW : low molecular weight/ high molecular weight;

$\mathrm{LMW}=\mathrm{Naph}+\mathrm{Acy}+\mathrm{Ace}+\mathrm{Fl}+\mathrm{Phe}+\mathrm{An}+\mathrm{Fluo}+\mathrm{Pyr}$

$\mathrm{HMW}=\mathrm{BzA}+\mathrm{Chrys}+\mathrm{B}(\mathrm{b}+\mathrm{k}) \mathrm{Fl}+\mathrm{B}(\mathrm{e}) \mathrm{Py}+\mathrm{B}(\mathrm{a}) \mathrm{Py}+\mathrm{IndP}+\mathrm{DB}(\mathrm{a}, \mathrm{h}) \mathrm{An}+\mathrm{B}(\mathrm{g}, \mathrm{h}, \mathrm{i}) \mathrm{P}$;

The abundance ratio of isomers of PAH unsubstituted parent / PAH isomers substituted (alkyl).

\section{CONCLUSION}

Hydrocarbons are widespread contaminants in river, lagoon, marine and coastal zones which majority consist of $n$ alkanes and PAHs. These compounds were introduced into the marine environment from some different sources including incomplete combustion of organic material (i.e. pyrogenic origin), discharge of petroleum and its products (petrogenic origin), a post-depositional transformation of biogenic precursors (i.e. diagenetic sources). The use of molecular diagnostic ratios could predict petroleum contamination or origin input to marine sediment but we have to take into consideration the inconsistent results from the literature compiled environmental samples. The ratios can also be misleading if samples are originated from more than one source that lead to inaccurate indication of apportionment source. Combined application of isotopic approach e.g. $\delta^{13} \mathrm{C}$ and molecular ratios in sediment may be a reliable way to perform a detail and qualitative study for multiple-source of apportionment.

\section{REFERENCES}

Asia, L., Mazouz, S., Guiliano, M., Doumenq, P., \& Mille, G. (2009). Occurrence and distribution of hydrocarbons in surface sediments from Marseille Bay (France). Marine Pollution Bulletin, 58(3), 443-51.

http://doi.org/10.1016/j.marpolbul.2 008.11 .022

Barakat, A. O., Qian, Y., Kim, M., \& Kennicutt Ii, M. C. (2002). Compositional Changes of Aromatic Steroid Hydrocarbons in Naturally Weathered Oil Residues in the Egyptian Western Desert. Environmental Forensics, 3(3-4), 219-225. 
http://doi.org/10.1080/713848375

Bray , E., Evans, D.D. (1961). Distribution of n-paraffin as a clue to recognition of source of beds. Geochimica et Cosmochimica Acta, 22, 2-15. http://doi.org/ 10.1016/0016-7037(61)90069-2

Budzinski, H., Jones, I., Bellocq, J., Piérard, C., \& Garrigues, P. (1997). Evaluation of sediment contamination by polycyclic aromatic hydrocarbons in the Gironde estuary. In Marine Chemistry (Vol. 58, pp. 85-97). http://doi.org/10.1016/S03044203(97)00028-5

Commendatore, M. G., Nievas, M. L., Amin, O., \& Esteves, J. L. (2012). Sources and distribution of aliphatic and polyaromatic hydrocarbons in coastal sediments from the Ushuaia Bay (Tierra del Fuego, Patagonia, Argentina). Marine Environmental Research, 74, 20-31. http://doi.org/10.1016/j.marenvres.2 011.11 .010

Culotta, L., Gianguzza, A., \& Orecchio, S. (2005). Leaves of Nerium oleander L. as bioaccumulators of Polycyclic Aromatic Hydrocarbons (PAH) in the air of Palermo (Italy): Extraction and GC-MS analysis, distribution and sources. Polycyclic Aromatic Compounds, 25(4), 327-344. http://doi.org/10.1080/10406630500 227262

Drozdova, S., Ritter, W., Lendl, B., \& Rosenberg, E. (2013). Challenges in the determination of petroleum hydrocarbons in water by gas chromatography (hydrocarbon index). Fuel, 113, 527-536. http://doi.org/10.1016/j.fuel.2013.03 .058

Farrington, J. W., \& Quinn, J. G. (2015). "Unresolved Complex Mixture" (UCM): A brief history of the term and moving beyond it. Marine Pollution Bulletin, 96(1), 29-31. http://doi.org/10.1016/j.marpolbul.2
015.04.039

Ficken, K. ., Wooller, M. ., Swain, D. ., Street-Perrott, F. ., \& Eglinton, G. (2002). Reconstruction of a subalpine grass-dominated ecosystem, Lake Rutundu, Mount Kenya: a novel multi-proxy approach. Palaeogeography, Palaeoclimatology, Palaeoecology, 177(1), 137-149. http://doi.org/10.1016/S00310182(01)00356-X

Harris, K. A., Yunker, M. B., Dangerfield, N., \& Ross, P. S. (2011). Sedimentassociated aliphatic and aromatic hydrocarbons in coastal British Columbia, Canada: Concentrations, composition, and associated risks to protected sea otters. Environmental Pollution, 159(10), 2665-2674. http://doi.org/10.1016/j.envpol.2011 .05 .033

INERIS, Pichard, A., Bisson, M., Houeix, N., Gay, G., Lacroix, G., ... Gillet, C. (2015). Fiche de données toxicologiques et environnementales des substances chimiques - Cuivre et ses dérivés. Ineris, 1-66.

Kanzari, F., Syakti, A. D., Asia, L., Malleret, L., Piram, A., Mille, G., \& Doumenq, P. (2014). Distributions and sources of persistent organic pollutants (aliphatic hydrocarbons, PAHs, PCBs and pesticides) in surface sediments of an industrialized urban river (Huveaune), France. Science of The Total Environment, 478, 141-151. http://doi.org/10.1016/j.scitotenv.20 14.01.065

Koch, B. P., Souza Filho, P. W. M., Behling, H., Cohen, M. C. L., Kattner, G., Rullk??tter, J., ... Lara, R. J. (2011). Triterpenols in mangrove sediments as a proxy for organic matter derived from the red mangrove (Rhizophora mangle). Organic Geochemistry, 42(1), 6273.

http://doi.org/10.1016/j.orggeochem 
.2010 .10 .007

Liu, Z., Liu, J., Gardner, W. S., Shank, G. C., \& Ostrom, N. E. (2016). The impact of Deepwater Horizon oil spill on petroleum hydrocarbons in surface waters of the northern Gulf of Mexico. Deep Sea Research Part II: $\quad$ Topical Studies in Oceanography, 129, 292-300. http://doi.org/10.1016/j.dsr2.2014.0 1.013

Marzi, R., Torkelson, B. E., \& Olson, R. K. (1993). A revised carbon preference index. Organic Geochemistry, 20(8), 1303-1306. http://doi.org/10.1016/01466380(93)90016-5

McIntyre, C. P., Harvey, P. M., Ferguson, S., Wressnig, A. M., Snape, I., \& George, S. C. (2007). Determining the extent of weathering of spilled fuel in contaminated soil using the diastereomers of pristane and phytane. Organic Geochemistry, 38(12), 2131-2134. http://doi.org/10.1016/j.orggeochem .2007 .07 .010

Meyers, P. a. (2003). Applications of organic geochemistry to paleolimnological reconstructions: a summary of examples from the Laurentian Great Lakes. Organic Geochemistry, 34(2), 261-289. http://doi.org/10.1016/S01466380(02)00168-7

Meyers, P. a. (1997). Organic geochemical proxies of paleoceanographic, paleolimnologic, and paleoclimatic processes. Organic Geochemistry, 27(5-6), 213-250.

http://doi.org/10.1016/S01466380(97)00049-1

Mille, G., Asia, L., Guiliano, M., Malleret, L., \& Doumenq, P. (2007). Hydrocarbons in coastal sediments from the Mediterranean sea (Gulf of Fos area, France). Marine Pollution Bulletin, 54(5), 566-75. http://doi.org/10.1016/j.marpolbul.2
006.12.009

Morrison, R. D. (2000). Critical Review of Environmental Forensic Techniques: Part I. Environmental Forensics, 1(4), 157-173. http://doi.org/10.1006/enfo.2000.00 17

Nayar, S., Goh, B. P. ., \& Chou, L. . (2004). The impact of petroleum hydrocarbons (diesel) on periphyton in an impacted tropical estuary based on in situ microcosms. Journal of Experimental Marine Biology and Ecology, 302(2), 213232.

http://doi.org/10.1016/j.jembe.2003. 10.016

Omotoye, S. J., Adekola, S. A., Adepoju, A., \& Akinlua, A. (2016). Thermal Maturity Assessment and Characterization of Selected Oil Samples from the Niger Delta, Nigeria. Energy and Fuels, 30(1), 104-111.

http://doi.org/10.1021/acs.energyfue 1s.5b01902

Perra, G., Pozo, K., Guerranti, C., Lazzeri, D., Volpi, V., Corsolini, S., \& Focardi, S. (2011). Levels and spatial distribution of polycyclic aromatic hydrocarbons (PAHs) in superficial sediment from 15 Italian marine protected areas (MPA). Marine Pollution Bulletin, 62(4), 874-877.

http://doi.org/10.1016/j.marpolbul.2 011.01 .023

Rajput, P., Sarin, M. M., Sharma, D., \& Singh, D. (2014). Atmospheric polycyclic aromatic hydrocarbons and isomer ratios as tracers of biomass burning emissions in Northern India. Environmental Science and Pollution Research, 21(8), 5724-5729. http://doi.org/10.1007/s11356-0142496-5

Resmi, P., Manju, M. N., Gireeshkumar, T. R., Ratheesh Kumar, C. S., \& Chandramohanakumar, N. (2016). 
Source characterisation of Sedimentary organic matter in mangrove ecosystems of northern Kerala, India: Inferences from bulk characterisation and hydrocarbon biomarkers. Regional Studies in Marine Science, 7, 43-54. http://doi.org/10.1016/j.rsma.2016.0 5.006

Rontani, J.-F., \& Bonin, P. (2011). Production of pristane and phytane in the marine environment: role of prokaryotes. Research in Microbiology, 162(9), 923-33. http://doi.org/10.1016/j.resmic.2011. 01.012

Short, J. W., \& Springman, K. R. (2016). 24 - Identification of hydrocarbons in biological samples for source determination. In Standard Handbook Oil Spill Environmental Forensics (pp. 1039-1069). http://doi.org/10.1016/B978-0-12803832-1.00024-6

Sikes, E. L., Uhle, M. E., Nodder, S. D., \& Howard, M. E. (2009). Sources of organic matter in a coastal marine environment: Evidence from nalkanes and their $\delta 13 \mathrm{C}$ distributions in the Hauraki Gulf, New Zealand. Marine Chemistry, 113(3-4), 149163.

http://doi.org/10.1016/j.marchem.20 08.12.003

Sprovieri, M., Feo, M. L., Prevedello, L., Manta, D. S., Sammartino, S., Tamburrino, S., \& Marsella, E. (2007). Heavy metals, polycyclic aromatic hydrocarbons and polychlorinated biphenyls in surface sediments of the Naples harbour (southern Italy). Chemosphere, 67(5), 998-1009. http://doi.org/10.1016/j.chemospher e.2006.10.055

Syakti, A. D., Mazzella, N., Nerini, D., Guiliano, M., Bertrand, J., \& Doumenq, P. (2006). Phospholipid fatty acids of a marine sedimentary microbial community in a laboratory microcosm: Responses to petroleum hydrocarbon contamination. Organic Geochemistry, 37(11), 1617-1628.

http://doi.org/10.1016/j.orggeochem .2006.01.009

Syakti, A. D., Asia, L., Kanzari, F., \& Umasangadji, H. (2012). Distribution of organochlorine pesticides ( OCs ) and polychlorinated biphenyls ( PCBs ) in marine sediments directly exposed to wastewater from Cortiou Marseille, 1524-1535. http://doi.org/10.1007/s11356-0110640-z

Syakti, A. D., Hidayati, N. V., Hilmi, E., Piram, A., \& Doumenq, P. (2013). Source apportionment of sedimentary hydrocarbons in the Segara Anakan Nature Reserve, Indonesia. Marine Pollution Bulletin, $\quad 74(1), \quad$ 141-148. http://doi.org/10.1016/j.marpolbul.2 013.07 .015

Syakti, A. D., Mazzella, N., Torre, F., Acquaviva, M., Gilewicz, M., Guiliano, M., ... Doumenq, P. (2006). Influence of growth phase on the phospholipidic fatty acid composition of two marine bacterial strains in pure and mixed cultures. Research in Microbiology, 157(5), 479-86.

http://doi.org/10.1016/j.resmic.2005. 11.001

Wang, X., Xu, H., Zhou, Y., Wu, C., \& Kanchanopas-Barnette, P. (2015). Distribution and source apportionment of polycyclic aromatic hydrocarbons in surface sediments from Zhoushan Archipelago and Xiangshan Harbor, East China Sea. Marine Pollution Bulletin (Vol. 101).

Wang, Z., Yang, C., Kelly-Hooper, F., Hollebone, B. P., Peng, X., Brown, C. E., ... Yang, Z. (2009). Forensic differentiation of biogenic organic compounds from petroleum 
hydrocarbons in biogenic and petrogenic compounds crosscontaminated soils and sediments. Journal of Chromatography A, 1216(7), 1174-1191. http://doi.org/10.1016/j.chroma.200 8.12.036

Yan, J., Liu, J., Shi, X., You, X., \& Cao, Z. (2016). Polycyclic aromatic hydrocarbons (PAHs) in water from three estuaries of China: Distribution, seasonal variations and ecological risk assessment. Marine Pollution Bulletin, 109(1), 471-479. http://doi.org/10.1016/j.marpolbul.2 016.05.025

Yunker, M. B., \& Macdonald, R. W. (2003). Alkane and PAH depositional history, sources and fluxes in sediments from the Fraser River Basin and Strait of Georgia, Canada. Organic Geochemistry, 34(10), 1429-1454. http://doi.org/10.1016/S01466380(03)00136-0

Zheng, B., Wang, L., Lei, K., \& Nan, B. (2016). Distribution and ecological risk assessment of polycyclic aromatic hydrocarbons in water, suspended particulate matter and sediment from Daliao River estuary and the adjacent area, China. Chemosphere, 149, 91-100. http://doi.org/10.1016/j.chemospher e.2016.01.039 